\title{
Platelet to lymphocyte ratio predicts all-cause mortality in patients with carotid arterial disease
}

\author{
MUJGAN TEK*, MEHMET SERKAN ÇETIN, ERDEM DIKKER, SAVAŞ ÇELEBİ, \\ BASRI AMASYALI, BERKTEN BERKALP
}

TOBB Economy and Technology University Cardiology Department, Ankara, Turkey

\begin{abstract}
Background. Platelet to lymphocyte ratio (PLR) has been demonstrated as a risk and prognostic marker in many of cardiovascular diseases. A relationship between PLR and severity of carotid stenosis has been shown. The aim of our study was to investigate the relationship between PLR and all cause mortality in patients with carotid arterial disease.

Methods. This retrospective study included 146 patients who had been performed selective carotid angiography. Carotid stenosis were graded by the North American Symptomatic Carotid Endarterectomy Trial (NASCET) criteria. Platelet to lymphocyte ratio was calculated as the ratio of platelets to lymphocytes. The end point of the study was all-cause mortality.

Results. During median follow-up of 16 months (0-65 months) 15 (10.3\%) patients suffered all-cause mortality. 50 patients $(34.2 \%)$ underwent carotid endarterectomy and 69 patients $(47.3 \%)$ had non-carotid cardiac surgery. 38 patients $(26.02 \%)$ had cerebrovascular events (stroke/transient ischemic attack) at admission. NASCET grades were not different between survivors and nonsurvivors. Non-survivors had significantly lower hemoglobin $(\mathrm{Hb})$ levels $(12.7 \pm 1.6 \mathrm{~g} / \mathrm{dL}$ vs. $13.7 \pm 1.7$ $\mathrm{g} / \mathrm{dL}, \mathrm{p}=0.031)$ and they were older than survivors $(74.2 \pm 8.4$ years $v s .68 .6 \pm 8.5$ years, $\mathrm{p}=0.029)$. Non-survivors had significantly higher PLR values compared with survivors $(190.3 \pm 85.6$ and $126.8 \pm$ $53.8, \mathrm{p}=0.017)$. In multivariate analysis, only PLR predicted all-cause mortality in patients with carotid artery stenosis.

Conclusion. In our study, higher PLR was associated with increased all-cause mortality.
\end{abstract}

Key words: platelet count, lymphocyte count, carotid artery disease, carotid stenosis, mortality.

\section{INTRODUCTION}

Previous studies showed that higher platelet and lower lymphocyte counts are associated with the formation of vascular diseases [1,2]. The platelet to lymphocyte ratio (PLR) is a new widely used inflammatory marker that combines information from both pathways of hemostasis and inflammation $[3,4]$. İt is suggested more useful than platelet and lymphocyte count alone. İncreased PLR has been shown to be associated with a number of clinical conditions involving cardiovascular diseases [ 5-8].

Stroke is one of the leading causes of death in the world. Carotid artery stenosis is an important atherosclerotic disease that may cause stroke [9]. The degree of carotid arterial stenosis is a risk factor for stroke development [10]. The relationship between PLR and severity of carotid stenosis and stroke has been shown [11, 12], but mortality relation is not known yet.

The aim of our study was to investigate the relationship between PLR and all cause mortality in patients with carotid arterial disease.

\section{MATERIALS AND METHOD}

This retrospective study included 146 patients who had been performed selective carotid angiography because of moderate to high extracranial internal carotid artery stenosis determined on Doppler carotids ultrasonography at TOBB ETÜ Hospital, Ankara, from January 2013 to June 2018. The majority of the study group were patients who were undergoing carotids Doppler ultrasonography before coronary artery bypass surgery.

Diagnostic Carotid angiographies had been performed by experienced interventional cardiologists using the conventional method. The degree of stenosis was assessed according to the North American Symptomatic Carotid Endarterectomy Trial (NASCET) criteria [13].

Clinical and demographic data were recorded from hospital medical records. Coronary artery disease was defined as angiographical presence of $\geq 50 \%$ stenosis in a major coronary artery or previous percutaneous coronary intervention/surgery for a stenotic coronary artery. Hypertension was 
defined as a previous diagnosis or current use of antihypertensive medications. Diabetes was defined as a previous diagnosis or current use of antidiabetic medications. Smoking was defined as current, regular use of cigarettes. Cerebrovascular events (CVE) were diagnosed as past history of any ischemic cerebrovascular event with or without sequela and transient ischemic attack diagnosed by an expert neurologist.

Laboratory data of venous blood sampling including hematologic and biochemical parameters performed before angiography were recorded. Platelet to lymphocyte ratio was calculated as the ratio of platelets to lymphocytes obtained from the same blood samples.

Patients with vertebral artery/subclavian artery stenosis, arterial dissection or aneurysm, atrial fibrillation that would lead to stroke/TİA evidence of active infection, chronic inflammatory or autoimmune diseases, cancer or hematological diseases and patients receiving antibiotic and steroid therapy were excluded from the study.

The end point of the study was all-cause mortality. Survival status during follow-up period was assessed using the national death notification system. The institutional ethics committee approved the study protocol.

\section{Statistical analysis}

All statistical analyses were performed using the SPSS 25 (SPSS INC, Chicago, Illinois, USA). Categorical variables were expressed as frequencies and continuous variables as mean \pm Standard deviation. The independent-sample t-test was used for continuous variables, and the chi-square test was used for categorical variables. Univariate Cox regression analysis was performed to assess the association of the variables with mortality and variables that had $p<0.250$ in the univariate analysis were further analyzed with multivariate Cox regression model. ROC curve was used to detect the optimal cut-off point of PLR to estimate all cause mortality. The best cut-off value for PLR was selected by the use of the Youden index. Kaplan-Meier survival curves used to assess survival times and log-rank statistics were used to test survival time differences between upper and lower cut-off point of PLR. A calculated difference of $p<0.05$ was considered to be statistically significant.

\section{RESULTS}

146 patients with carotid artery stenosis were included in the study (mean age $69.2 \pm 8.6$ years with 110 males). The median follow-up was 16 months (0-65 months). A total of 15 deaths occurred. Table 1 provides a comparison between survivors and non-survivors. Non-survivors had significantly lower $\mathrm{Hb}$ levels $(12.7 \pm 1.6 \mathrm{~g} / \mathrm{dL} v s$. $13.7 \pm 1.7 \mathrm{~g} / \mathrm{dL}, \mathrm{p}=0.031)$ and they were older than survivors $(74.2 \pm 8.4$ years $v s .68 .6 \pm 8.5$ years, $\mathrm{p}=0.029$ ). The rates of CVEs at admission were higher in non-survivors than in survivors (40\% vs. $24.4 \%, p=0.294)$. There was no statistically significant difference between the groups in terms of the degree of carotids artery stenosis according to NASCET classification . The rates of patients treated with carotid endarterectomy during follow-up period were similar between groups (35.1\% in survivors and $26.6 \%$ in non-survivors, $\mathrm{p}=$ $0.366)$. Non-survivors had significantly higher PLR values compared with survivors $(190.3 \pm 85.6$ and $126.8 \pm 53.8, \mathrm{p}=0.017)$.

Univariate Cox regression analysis found that all-cause mortality was associated with age $(p=$ 0.079), diabetes mellitus (DM) $(\mathrm{p}=0.0229)$, smoking status $(p=0.219)$, ejection fraction $(E F)(p=$ $0.128)$, high-density lipoprotein (HDL) $(p=0.140)$, $\mathrm{Hb}(\mathrm{p}=0.08)$ and PLR $(\mathrm{p}=0.027)$. After multivariate Cox regression analysis, only PLR was found to be an independent predictor of all-cause mortality (Table 2).

The ROC analysis was performed to determine the PLR cut-off value to predict allcause mortality. The ROC curve is shown in Figure 1. The PLR was predictive at 131.07 with $64 \%$ sensitivity and $36 \%$ specificity (95\% CI: $0.603-0.867, \mathrm{p}=0.004$; area under the curve: $0.735)$.

Study population was dichotomized based on the cut-off PLR value of 131.07. Figure 2 shows Kaplan-Meier analysis of cumulative survival according to PLR value $(\geq 131.07$ or $<131.07)$ in patients with carotid artery disease. Patients with $P L R \geq 131.07$ had a higher incidence of all-cause mortality compared with patients with PLR < $131.07(\log \operatorname{rank} \mathrm{p}=0.062)$. 
Table 1

Baseline Characteristics of Patients According to the Survival Status

\begin{tabular}{lccc}
\hline \multicolumn{1}{c}{ Variables } & Survivors & Non-survivors & P value \\
& $\mathbf{n}=\mathbf{1 3 1}$ & $\mathbf{n = 1 5}$ & \\
\hline Age, years & $68.6 \pm 8.5$ & $74.2 \pm 8.4$ & $\mathbf{0 . 0 2 9}$ \\
Gender, male, n(\%) & $99(75.5)$ & $11(73.3)$ & 0.849 \\
CAD, n (\%) & $110(83.9)$ & $13(86.6)$ & 0.698 \\
HT, n(\%) & $105(80.1)$ & $13(86.6)$ & 0,468 \\
Smoking, n(\%) & $39(29.7)$ & $3(20)$ & 0.431 \\
DM, n (\%) & $48(36.6)$ & $4(26.6)$ & 0.771 \\
LEAD, n (\%) & $33(25.1)$ & $2(13.3)$ & 0.487 \\
CVE, n (\%) & $32(24.4)$ & $6(40)$ & 0.294 \\
Glucose, mg/dL & $139.4 \pm 59.7$ & $131.5 \pm 56.6$ & 0.632 \\
GFR, mL/dk/1.73 m ${ }^{2}$ & $73 \pm 18.9$ & $70 \pm 23.5$ & 0.768 \\
CRP, mg/L & $5.3 \pm 6.6$ & $7.8 \pm 5.2$ & 0.263 \\
Total cholesterol, mg/dL & $185.8 \pm 56.7$ & $187.3 \pm 43.8$ & 0.917 \\
Triglyceride, mg/dL & $151 \pm 75.2$ & $131 \pm 60.8$ & 0.330 \\
LDL, mg/dL & $119.3 \pm 48.9$ & $104.3 \pm 43.4$ & 0.243 \\
HDL, mg/dL & $40.7 \pm 10.4$ & $47.6 \pm 22.2$ & 0.336 \\
Hemoglobin, g/dL & $13.7 \pm 1.7$ & $12.7 \pm 1.6$ & $\mathbf{0 , 0 3 1}$ \\
Platelet, 10 ${ }^{3}$ u/L & $241.2 \pm 77.7$ & $221,5 \pm 54.13$ & 0,234 \\
Lymphocyte, 10 3 u/L & $2.2 \pm 0.87$ & $1.9 \pm 0,89$ & 0.194 \\
PLR & $126,8 \pm 53.8$ & $190.3 \pm 85.6$ & $\mathbf{0 . 0 1 7}$ \\
LVEF, \% & $55.02 \pm 9.2$ & $50.6 \pm 11.9$ & 0.263 \\
Carotid endarterectomy, n (\%) & $46(35.1)$ & $4(26.6)$ & 0.366 \\
Non-carotid cardiac surgery, n (\%) & $60(45.8)$ & $9(60)$ & 0.221 \\
Antiplatelet, n (\%) & $116(88.5)$ & $12(80)$ & 0.230 \\
Statin, n (\%) & $87(66.4)$ & $8(53.3)$ & 0.736 \\
NASCET, n (\%) & & & \\
I-II-III (normal-50\% stenosis) & $56(42.7)$ & $7(46.6)$ & 0.655 \\
IV-Va(50-85\% stenosis) & $31(23.6)$ & $2(13.3)$ & 0.627 \\
Vb-VI(85\%-occluded) & $44(33.5)$ & $6(40)$ & 0,917 \\
\hline
\end{tabular}

Abbreviations: CAD, Coronary artery disease; HT, hypertension; DM, Diabetes mellitus; LEAD, Lower extremity arterial disease; CVE, Cerebrovascular events; GFR, glomerular filtration rate; CRP, $\mathrm{C}$ reactive protein; LDL, low-density lipoprotein; HDL,high density lipoprotein; PLR, platelet to lymphocyte ratio; LVEF, left ventricular ejection fraction.

Table 2

Predictors of all-cause mortality in multivariate Cox regression analysis

\begin{tabular}{lcc}
\hline \multicolumn{1}{c}{ Variables } & OR (95\% CI) & p \\
\hline Age, years & $1.070(0.978-1.172)$ & 0.141 \\
DM, yes & $0.706(0.158-3.161)$ & 0.649 \\
Smoking, yes & $0.434(0.052-3.610)$ & 0.440 \\
LVEF, \% & $0.968(0.906-1.035)$ & 0.342 \\
Hemoglobin, g/dL & $1.042(0.678-1.601)$ & 0.852 \\
PLR & $0.010(1.002-1.018)$ & 0.009 \\
HDL, mg/dL & $1.041(0.998-1.086)$ & 0.065 \\
\hline
\end{tabular}


ROC Curve

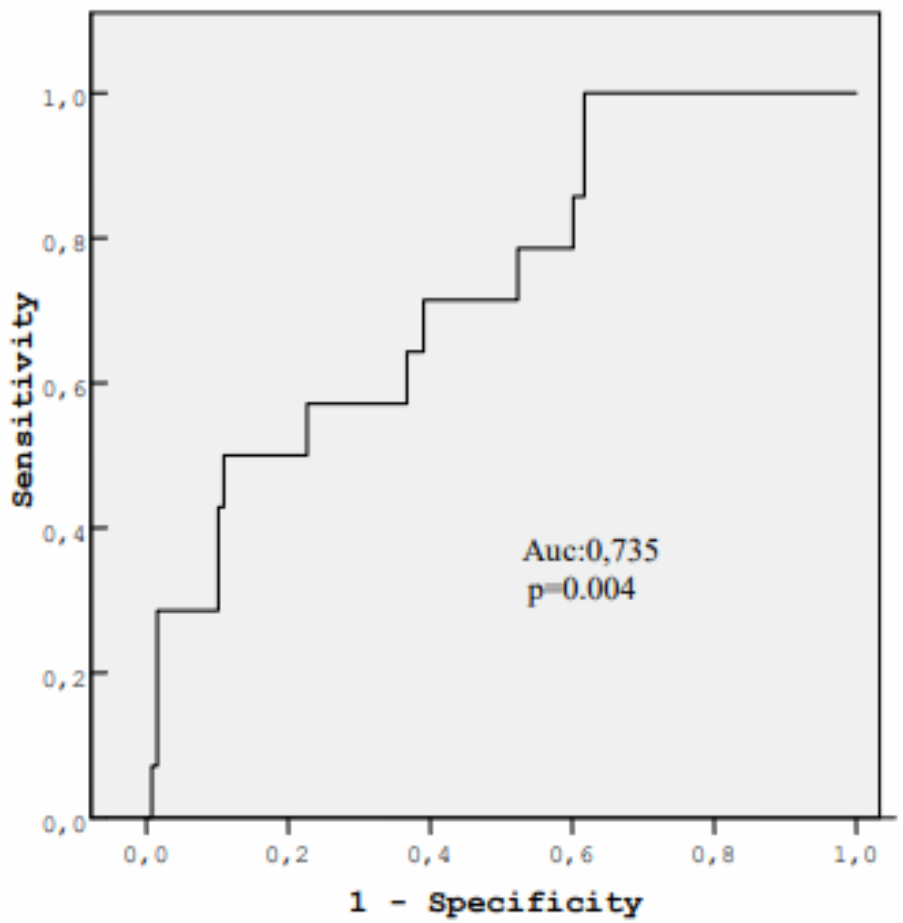

Figure 1. Receiver-operating characteristic curve of PLR for predicting all-cause mortality. Auc indicates area under the curve.

\section{Survival Functions}

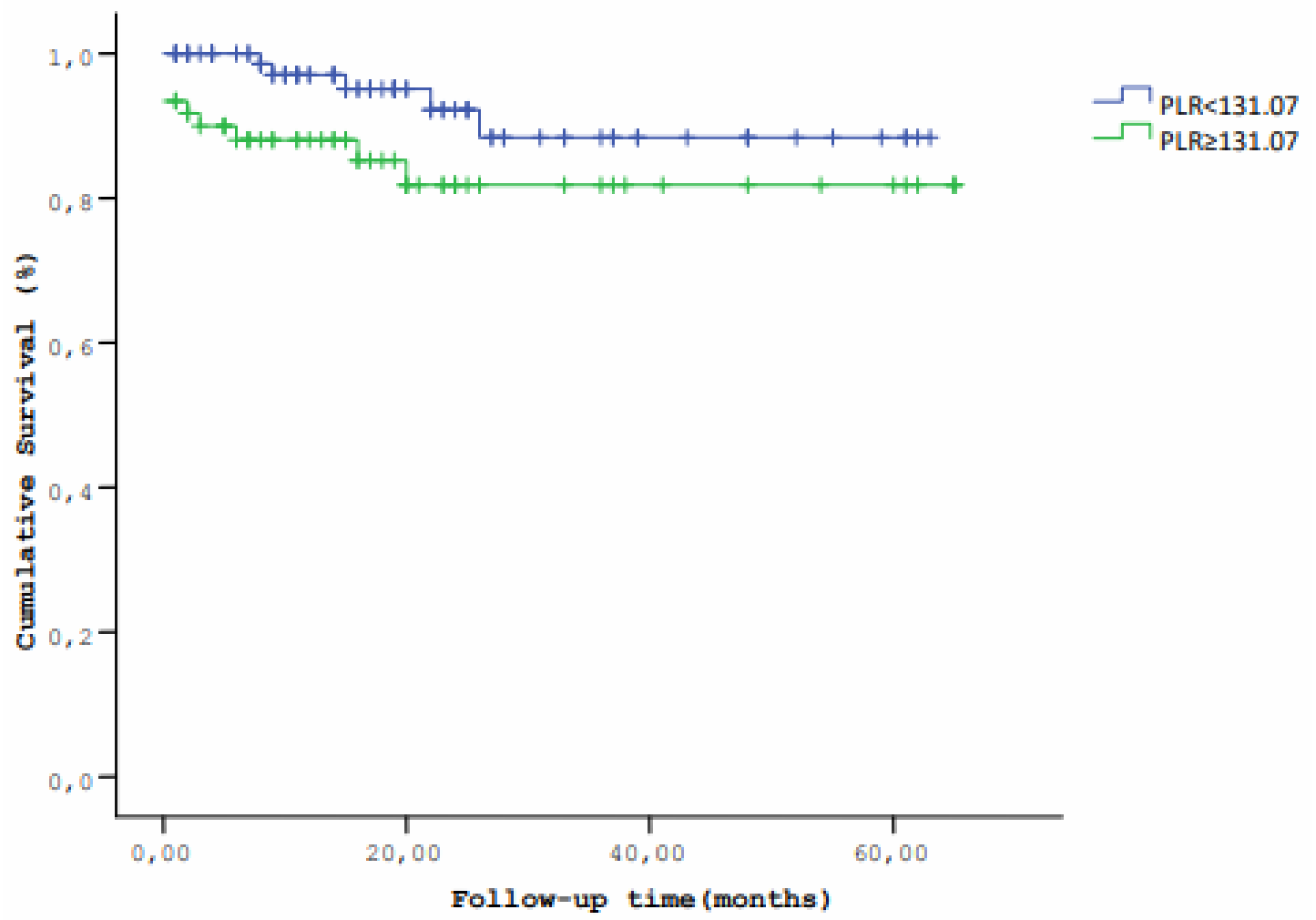

Figure 2. Kaplan-Meier survival curves according to cut-off PLR value. 


\section{DISCUSSION}

In the present study, we found that PLR is an independent predictor of all-cause mortality in patients with carotid artery stenosis. We demonstrated that PLR predicts all-cause mortality independent of severity of carotid artery stenosis and associated risk factors.

PLR is a novel marker which indicates inflammation indirectly [14]. It has been demonstrated as an independent risk marker in many of cardiovascular diseases including coronary artery disease, heart failure, calcific aortic stenosis and atrial fibrillation [3, 15-17]. In addition to being a risk marker in cardiovascular field, PLR is also as a prognostic marker which shows mortality and other worse outcomes such as no-reflow phenomenon, impaired infarct artery patency, increased in hospital and short term mortality [18-22]. Lee et al. [4] demonstrated that elevated PLR is associated with long term all-cause mortality in patients at high risk of coronary artery disease who underwent coronary angiography in their study. Azab et al. [23] reported PLR $>176$ is a significant independent predictor of long term mortality after NSTEMI. Osadnik et al. [24] reported PLR as a predictor of all-cause mortality in patients with coronary artery disease undergoing elective percutaneous coronary intervention and stent implantation.

Carotid artery stenosis is a serious condition that is usually caused by atherosclerosis [25]. As with coronary atherosclerosis, inflammation plays a pivotal role in carotid atherosclerosis from initiation through progression [26]. The association between increased PLR and carotid artery disease has been shown [11, 12]. Soylu et al. [11] reported that PLR has been associated with severity of carotid artery disease and is an independent predictor of stroke.
However, in our study PLR was not associated with the degree of carotid stenosis. In the aforementioned study of Soylu et al. maximum stenosis was different between the PLR tertiles. The discrepancy between computed tomography and invasive angiography for quantification of stenosis degree may explain this result. Computed tomograpy enables assessment of plaque remodeling and, therefore, especially in cases with positive remodeling, it tends to overestimate stenosis degree in contrast to invasive angiography, which is also regarded as luminography [27].

Despite previous cross-sectional studies showing the relationship between PLR and carotid artery stenosis, there has been any study investigating the prognostic role of PLR in patients with carotid artery stenosis. Therefore, our study is the first in the literature evaluating this relationship. We showed the effect of PLR on all-cause mortality independent of platelet or lymphocyte counts alone. Increased PLR reflects the augmented status of inflammation and thrombosis which can be associated with increased mortality in this patient group.

Our study has several limitations. Firstly, it is a single center retrospective study. Secondly our patient population was mostly of preoperative coronary bypass surgery patients which constitutes a specific patient population. And lastly, the lack of longitudinal data suggesting progression of carotid atherosclerosis may add incremental value to the study.

In conclusion, in our study, higher PLR was associated with increased all-cause mortality. Assessment of this easy available marker may be helpful for risk assessment in carotid artery.

Declaration of interest: The authors declared no conflict of interest.

Funding: No funding was received for this research of diseases.

Introducere. Raportul plachete-limfocite (PLR) este demonstrat a fi factor de risc şi prognostic pentru mai multe patologii cardiovasculare. Relația dintre PLR şi stenoza carotidiană este demonstrată. Scopul studiului este de a investiga relația dintre PLR şi mortalitatea la pacienții cu stenoză carotidiană.

Materiale şi metode. A fost realizat un studiu retrospectiv pe 146 de pacienți ce au avut angiografie carotidiană selectivă. Stenoza carotidiană a fost evaluată conform criteriilor NASCET (North American Symptomatic Carotid Endarterectomy Trial). A fost calculat PLR. Efectul măsurat al studiului a fost mortalitatea de orice cauză.

Rezultate. Pacienții au fost urmăriți 16 luni în medie (0-65 luni). La 15 pacienți (10.3\%) a survenit decesul. 50 de pacienți (34.2\%) au suferit endarterectomie carotidiană şi 69 de pacienți au suferit chirurgie cardiacă non carotidiană. 38 de pacienți $(26.02 \%)$ au suferit evenimente cerebrovasculare (atacuri vasculare 
ischemice sau tranzitorii). Pacienții care nu au supraviețuit au avut niveluri semnificative statistic mai mici ale hemoglobinei $(12.7 \pm 1.6 \mathrm{~g} / \mathrm{dl}$ vs. $13.7 \pm$ $1.7 \mathrm{~g} / \mathrm{dl}, \mathrm{p}=0.031)$ şi erau mai în vârstă decât pacienții care au supraviețuit $(74.2 \pm$ 8.4 ani vs. $68.6 \pm 8.5$ ani, $p=0.029)$. Pacienții care $n u$ au supraviețuit au avut valori semnificativ mai mari ale PLR (190.3 \pm 85.6 şi $126.8 \pm 53.8, p=0.017)$. In analiza multivariată numai PLR a prezis independent mortalitatea la pacienții cu stenoză carotidiană.

Concluzii. In acest studiu valori crescute ale PLR s-au asociat cu mortalitatea la pacienții cu stenoză carotidiană.

Correspondence to: Müjgan Tek, M.D, TOBB Economy and Technology University Cardiology Department, Ankara, Turkey, Tel: +90-312-292 9900

E-mail: drmujgantek@hotmail.com,mtek@tobbetuhastanesi.com.tr

\section{REFERENCES}

1. KAPLAN ZS., JACKSON SP. The role of platelets in atherothrombosis. Hematology Am Soc Hematol Educ Program 2011; 2011:51-61.

2. OMMEN SR., GIBBONS RJ., HODGE DO., THOMPSON SP. Usefulness of the lymphocyte concentration as a prognostic marker in coronary artery disease. Am J Cardiol 1997:79;812-4.

3. PETERSEN AK., KRUMSIEK J., WÄGELE B., THEİS FJ., WICHMANN HE., GİEGER C. On the hypothesis-free testing of metabolite ratios in genome-wide and metabolome-wide association studies. BMC Bioinformatics. 2012 Jun 6;13:120.

4. LEE YSG., BARADİ A., PEVERELlE M., SULTANI R., ADAMS H, GARLİCK J., et al. Usefulness of Platelet-toLymphocyte Ratio to Predict Long-Term All-Cause Mortality in Patients at High Risk of Coronary Artery Disease Who Underwent Coronary Angiography. Am J Cardiol. 2018 May 1;121(9):1021-1026.

5. YÜKSEL M., YILDIZ A., OYLUMLU M., AKYÜZ A., AYDIN M., KAYA H., et al. The association between platelet/lymphocyte ratio and coronary artery disease severity. Anatol J Cardiol. 2015 Aug; 15(8):640-7.

6. BHATTI I., PEACOCK O., LLOYD G., LARVIN M., HALL RI. Preoperative hematologic markers as independent predictors of prognosis in resected pancreatic ductal adenocarcinoma: neutrophil-lymphocyte versus platelet-lymphocyte ratio. Am J Surg. 2010;200:197-203.

7. GURSOY OM., KARAKOYUN S., KALCIK M., GOKDENIZ T., YESIN M., GUNDUZ S., et al. Usefulness of novel hematologic inflammatory parameters to predict prosthetic mitral valve thrombosis. Am J Cardiol. 2014;113:860-864.

8. GARY T., PICHLER M., BELAJ K., HAFNER F., GERGER A., FROEHLICH H., et al. Platelet-to-lymphocyte ratio: a novel marker for critical limb ischemia in peripheral arterial occlusive disease patients. PLoS One. 2013;8:e67688.

9. WITKİEWICZ W., KLIMECZEK P., IWANOWSKİ W., PASİCKA B., DOŁEGA-KOZİEROWSKİ B., DRELİCHOWSKİ S., et al. Dual source computed tomography in analysis of significance and morphology carotid plaques. Przegl Lek. 2013;70(3):118-122.

10. LİAPİS CD., BELL PR., MİKHAİLIDİSM D., et al. ESVS guidelines. Invasive treatment for carotid stenosis: indications, techniques. Eur J Vasc Endovasc Surg 2009; 37:1-19.

11. SOYLU İA., CORTCU SA., UZUNKAYA F., ATALAY YO., BEKÇİ T., GÜNGÖR L., et al. The correlation of the plateletto-lymphocyte ratio with the severity of stenosis and stroke in patients with carotid arterial disease. Vascular. 2017 Jun;25(3):299-306.

12. VARIM C., VARIM P., ACAR BA., VATAN MB., UYANIK MS., KAYA T., et al. Usefulness of the platelet-to-lymphocyte ratio in predicting the severity of carotid artery stenosis in patients undergoing carotid angiography. Kaohsiung Journal of Medical Sciences (2016) 32, 86-90.

13. MONETA GL, EDWARDS JM, TAYLOR LM JR, CHITWOOD RW, LEE RW, CUMMINGS CA et al. Correlation of North American Symtomatic Carotid Endarterectomy Trial (NASCET) angiographic definition of $70 \%$ to $99 \%$ internal carotid artery stenosis with duplex scanning. J Vase Surg. 1993;17(1):152-159.

14. BALTA S., OZTURK C. The platelet-lymphocyte ratio: A simple, inexpensive and rapid prognostic marker for cardiovascular events. Platelets. 2015;26(7):680-1.

15. DURMUŞ E., KIVRAK T., GERIN F., SUNBUL M., SARİ I., ERDOGAN O. Neutrophil-to-lymphocyte ratio and and Plateletto-Lymphocyte Ratio are Predictors of Heart Failure. Send to Arq Bras Cardiol. 2015 Dec;105(6):606-13.

16. AKDAĞ S., AKYOL A., ASKER M., DUZ R., GUMRUKCUOGLU HA. Platelet-to-Lymphocyte Ratio May Predict the Severity of Calcific Aortic Stenosis. Med Sci Monit. 2015 Nov 6;21:3395-400.

17. DERELI S., BAYRAMOĞLU A., YONTAR OC. Usefulness of platelet to lymphocyte ratiofor predicting recurrence of atrial fibrillation after direct current cardioversion. Ann Noninvasive Electrocardiol. 2018 Nov 10:e12616.

18. YILDIZ A., YUKSEL M., OYLUMLU M., POLAT N., AKYUZ A., ACET H., et al. The utility of the platelet-lymphocyte ratio for predicting no reflow in patients with ST-segment elevation myocardial infarction. Clin Appl Thromb Hemost 2015 Apr;21(3):223-8.

19. YAYLA Ç., AKBOĞA MK., CANPOLAT U. Platelet to lymphocyte ratio can be a predictor of infarct-related artery patency in patients with ST-segment elevation myocardial infarction. Angiology. 2015 Oct;66(9):831-6. 
20. TEMIZ A., GAZİ E., GÜNGÖR Ö. Platelet/lymphocyte ratio and risk of in-hospital mortality in patients with ST-elevated myocardial infarction. Med Sci Monit. 2014;20:660-665.

21. OZCAN CETIN EH., CETIN MS., ARAS D., TOPALOGLU S, TEMIZHAN A, KİSACIK HL., et al. Platelet to lymphocyte ratio as a prognostic marker of in-hospital and long-term major adverse cardiovascular events in-hospital and long-term major adverse cardiovascular events in ST segment elevation myocardial infarction. Angiology 2016;67:336-345.

22. AYÇA B., AKIN F., OKUYAN E. Platelet to lymphocyte ratio as a prognostic marker in primary percutaneous coronary intervention. Platelets. 2015;26(8):816.

23. AZAB B., SHAH N., AKERMAN M., MCGINN JT JR. Value of platelet/lymphocyte ratio as a predictor of all-cause mortality after non-ST-elevation myocardial infarction. J Thromb Thrombolysis. 2012 Oct;34(3):326-34.

24. OSADNIK T., WASILEWSKI J., LEKSTON A., STRZELCZYK J., KUREK A., GONERA M., et al. The platelet-tolymphocyte ratio as a predictor of all-cause mortality in patients with coronary artery disease undergoing elective percutaneous coronary intervention and stent implantation. Saudi Heart Assoc. 2015 Jul;27(3):144-51.

25. BOULOS NM., GARDIN JM., MALIK S., POSTLEY J., WONG ND. Carotid plaque characterization, stenosis, and intimamedia thickness according to age and gender in a large registry cohort. Am J Cardiol. 2016 Apr 1;117(7):1185-91.

26. HANSSON GK. Inflammation, atherosclerosis, and coronary artery disease. N Engl J Med 2005; 352:1685-95.

27. DOH JH., KOO BK., NAM CW., KIM JH., MIN JK., NAKAZATO R., et al. Diagnostic value of coronary CT angiography in comparison with invasive coronary angiography and intravascular ultrasound in patients with intermediate coronary artery stenosis: results from the prospective multicentre FIGURE-OUT (Functional Imaging criteria for GUiding REview of invasive coronary angiOgraphy, intravascular Ultrasound, and coronary computed Tomographic angiography) study. Eur Heart J Cardiovasc Imaging. 2014 Aug;15(8):870-7.

Received November 9, 2018 